\title{
An Analysis of Postharvest Fungal Pathogens Reveals Temporal-Spatial and Host-Pathogen Associations with Fungicide Resistance-Related Mutations
}

\author{
Michael J. Bradshaw, ${ }^{1, \dagger}$ Holly P. Bartholomew, ${ }^{1}$ Dylan Hendricks, ${ }^{2}$ Autumn Maust, ${ }^{2}$ and Wayne M. Jurick, $\mathrm{II}^{1}$ \\ ${ }^{1}$ Food Quality Laboratory, Agricultural Research Service, U.S. Department of Agriculture, Beltsville, MD 20705 \\ ${ }^{2}$ School of Environmental and Forest Sciences, University of Washington, Seattle, WA 98195 \\ Accepted for publication 29 April 2021.
}

ABSTRACT

\begin{abstract}
Fungicides are the primary tools to control a wide range of postharvest fungal pathogens. Fungicide resistance is a widespread problem that has reduced the efficacy of fungicides. Resistance to FRAC-1 (Fungicide Resistance Action Committee-1) chemistries is associated with mutations in amino acid position 198 in the $\beta$-tubulin gene. In our study, we conducted a meta-analysis of $\beta$-tubulin sequences to infer temporal, spatial, plant host, and pathogen genus patterns of fungicide resistance in postharvest fungal pathogens. In total, data were acquired from 2,647 specimens from 12 genera of fungal phytopathogens residing in 53 countries on $>200$ hosts collected between 1926 and 2020. The specimens containing a position 198 mutation were globally distributed in a variety of pathosystems. Analyses showed that there are associations among the mutation and the year an isolate was collected, the pathogen genus, the pathogen host, and the collection region. Interestingly, fungicide-resistant $\beta$-tubulin
\end{abstract}

genotypes have been in a decline since their peak between 2005 and 2009. FRAC-1 fungicide usage data followed a similar pattern in that applications have been in a decline since their peak between 1997 and 2003. The data show that, with the reduction of selection pressure, FRAC-1 fungicide resistance in fungal populations will decline within 5 to 10 years. Based on this line of evidence, we contend that a $\beta$-tubulin position 198 mutation has uncharacterized fitness cost(s) on fungi in nature. The compiled dataset can inform end users on the regions and hosts that are most prone to contain resistant pathogens and assist decisions concerning fungicide resistance management strategies.

Keywords: $\beta$-tubulin, FRAC 1 group, fungicide resistance, 198 mutation, postharvest fungal pathogens
The use of fungicides to control phytopathogens was first noted $>150$ years ago in France where a mixture of lime and copper sulfate, known as "Bordeaux mixture," was found to control fungal diseases in vineyards (Schumann 1991). Fungicides are an intricate part of agricultural systems and are a valuable asset that increases yield and agricultural efficiency. In 2012, an estimated 65 million pounds of fungicide active ingredients (costing $\$ 1.784$ billion) were applied in the United States (Atwood and Paisley-Jones 2017). The quantity of fungicides used is dependent on a variety of factors including the pathogen, the region, the crops grown, and the climate (Agrios 2005). Fungicide usage has been a valuable tool for the agriculture industry, but during the past 60 years, decreased fungicide efficacy stemming from fungicide resistance has been reported (Smith 1988).

Fungicide resistance was first reported in the Penicillium digitatumlemon system by Harding (1959). However, unlike insecticides and bactericides, fungicide resistance was not initially considered a problem, with only a few field cases reported in the 1960s (Georgopoulos 1969). The lag from the first usage of fungicides to the development of resistant isolates can most likely be attributed to the broad-spectrum nature of the fungicides originally available in the market. However, in the late 1960s, specific, single-site mode-of-action (MOA) chemistries began to be widely used to control a range of fungal phytopathogens (Georgopoulos 1969). For example, in 1968 a selective benzimidazole fungicide was introduced by Dupont with the trade

${ }^{\dagger}$ Corresponding author: M. J. Bradshaw; mjb34@uw.edu

Funding: This work was supported in part by the Agricultural Research Service Research Participation Program under Department of Energy contract DE-SC0014664.

*The $e$-Xtra logo stands for "electronic extra" and indicates one supplementary table is published online.

The author(s) declare no conflict of interest.

(C) 2021 The American Phytopathological Society name Benlate. Multiple authors reported that Fungicide Resistance Action Committee-1 (FRAC-1) fungicides (Table 1), provided systemic control for a variety of fungal diseases (Delp and Klopping 1968; Erwin et al. 1968; Freeman and Pepin 1967). Soon after the release of benomyl, a FRAC-1 fungicide, Schroeder and Provvidenti (1969) reported resistant strains of powdery mildew to FRAC-1 materials. Multiple authors followed suit with reports of resistance in other systems (Smith 1988). Fungicide resistance is a prevalent problem in the agriculture industry, predominately with single-site MOA chemistries. Resistance to FRAC-1 fungicides can occur within only a few years of fungicide applications (Jones and Walker 1976), and is especially prominent with postharvest pathogens where applications of FRAC-1 fungicides are used at high frequencies as a result of consumers' desire for produce with limited damage or blemishes from diseases.

FRAC-1 fungicides are valuable in that they have low toxicity to humans and have high efficacy on multiple postharvest pathogens on a range of crops (Table 2). Resistance to FRAC-1 fungicides has been reported in multiple postharvest fungal pathogens including those in the genera Botrytis, Colletotrichum, Phlyctema, Penicillium, Molinia, and Sclerotinia (Baraldi et al. 2003; Bolay et al. 1974; Bryk 1997; Chen et al. 2013; Chung et al. 2010; Koenraadt et al. 1992; Martin et al. 2021; Sholberg et al. 2005). Resistance in fungi within these genera has been associated with the $\beta$-tubulin region, where mutations inhibit a fungicide's ability to bind to tubulin, thus reducing its efficacy (Davidse 1973; Hastie and Georgopoulos 1971; Jung et al. 1992). Single-nucleotide mutations in multiple locations of the 198- and/or 200-position codon in the $\beta$-tubulin gene in multiple genera of postharvest pathogens have been found to be associated with resistance, with the E198A amino acid mutation being the most commonly reported (Baraldi et al. 2003; Buhr and Dickman 1994; Chen et al. 2009, 2013; Cosseboom and $\mathrm{Hu}$ 2021; Cosseboom et al. 2019; Koenraadt et al. 1992; Martin et al. 2021; Sholberg et al. 2005; Yarden and Katan 1993; Zhonghua et al. 2003). Advances in 
genomic technology allow screening of this region using PCR to predict fungicide resistance quickly and accurately (Banno et al. 2008; Luck and Gillings 1995; Luo et al. 2009; Ziogas et al. 2009).

In our study, we conducted a meta-analysis of the $\beta$-tubulin sequences available in GenBank, and throughout the literature, of common postharvest pathogens, to infer temporal-, spatial-, host-, and genus-level patterns of resistance. A meta-analysis is a study that synthesizes previously acquired data to gain a better understanding of the peer-reviewed literature and infer conclusions on a wide dataset collected in different settings. Meta-analyses focusing on common genetic variants increases the power to detect associations within a population compared with single studies (Lee 2015; Munafò and Flint 2004; Oliveira et al. 2018; Panagiotou et al. 2013). We decided to focus on mutations in the $\beta$-tubulin amino acid 198 position as this is the most consistent marker associated with resistance to FRAC-1 fungicides (Chung et al. 2010; Cosseboom and $\mathrm{Hu}$ 2021; Cosseboom et al. 2019; Sholberg et al. 2005). With the globalization of agricultural commodities, these data can inform farmers on what regions and hosts are most prone to contain resistant phytopathogens and can assist with regional dependent Integrated Pest Management (IPM) and fungicide resistance management strategies used in a variety of systems.

\section{MATERIALS AND METHODS}

Data collection. The meta-analysis included GenBank (NCBI), an annotated collection of all publicly available DNA sequences, as well as information from 203 peer-reviewed studies taken from throughout the world. We decided to focus strictly on postharvest pathogens and thus genera were chosen that consisted of species that caused considerable postharvest diseases to common agricultural crops. Examples of the genera chosen, and their corresponding postharvest disease and host plants, are presented in Table 2. In total, 12 fungal genera were evaluated: Alternaria, Aspergillus, Botrytis, Coleophoma, Colletotrichum, Fusarium, Monilinia, Neofabraea, Penicillium, Pezicula, Phylectema, and Sclerotinia. We evaluated all available species within each genus. The amino acid 198 position from the $\beta$-tubulin region was evaluated as a genetic marker for fungicide resistance because of the high affinity of mutations in this sequence to be correlated to resistance phenotypes in multiple systems (Buhr and Dickman 1994; Chen et al. 2009, 2013; Koenraadt et al. 1992; Ma et al. 2003; Sholberg et al. 2005; Yarden and Katan 1993). We decided to exclude the codon 200 position, as for many organisms this either was not reported to be associated with resistance, or was reported to be at lower association levels than that of the 198 position (Chung et al. 2010; Sholberg et al. 2005).

TABLE 1. List of commonly used Fungicide Resistance Action Committee-1 (FRAC-1) fungicides and their trade names for the control of phytopathogens, as well as their mode of action, active ingredients, and year the fungicide was introduced

\begin{tabular}{|c|c|c|c|c|}
\hline Commercial products $^{\mathrm{a}}$ & $\begin{array}{l}\text { FRAC-1 active } \\
\text { ingredient }\end{array}$ & Chemical group & Mode of action & $\begin{array}{c}\text { Year of } \\
\text { introduction }\end{array}$ \\
\hline $\begin{array}{l}\text { Agrocit, Benex, Benlate, Benosan, } \\
\text { Fundazol, Fungidice 1991, Tersan } \\
1991\end{array}$ & Benomyl & Benzimidazole & $\begin{array}{l}\beta \text {-tubulin assembly } \\
\quad \text { interference (mitosis) }\end{array}$ & 1967 \\
\hline $\begin{array}{l}\text { Delsene, Bavistin, Corbel, Konker, } \\
\text { Bedazim, Derosal, Kombat, } \\
\text { Kemdazin, Carbendor, Hoe 017411, } \\
\text { Cekudazim, Equitdazin, Aimcozim }\end{array}$ & Carbendazim & Benzimidazole & $\begin{array}{l}\beta \text {-tubulin assembly } \\
\quad \text { interference (mitosis) }\end{array}$ & 1968 \\
\hline $\begin{array}{l}\text { Arbotect, Mertect, Bioguard, Bovizole, } \\
\text { Eprofil, Equizole, Lombristop, } \\
\text { Metasol TK 100, Mintesole, } \\
\text { Mycozol, Nemapan, Omnizole, } \\
\text { Polival, Tebuzate, Tecto, Thibenzole } \\
\text { 200, Thiprazole, Top Form Wormer, } \\
\text { Agrosol }\end{array}$ & Thiabendazole & Benzimidazole & $\begin{array}{l}\beta \text {-tubulin assembly } \\
\text { interference (mitosis) }\end{array}$ & 1968 \\
\hline
\end{tabular}

TABLE 2. Postharvest pathogens evaluated in this study and the diseases associated with them

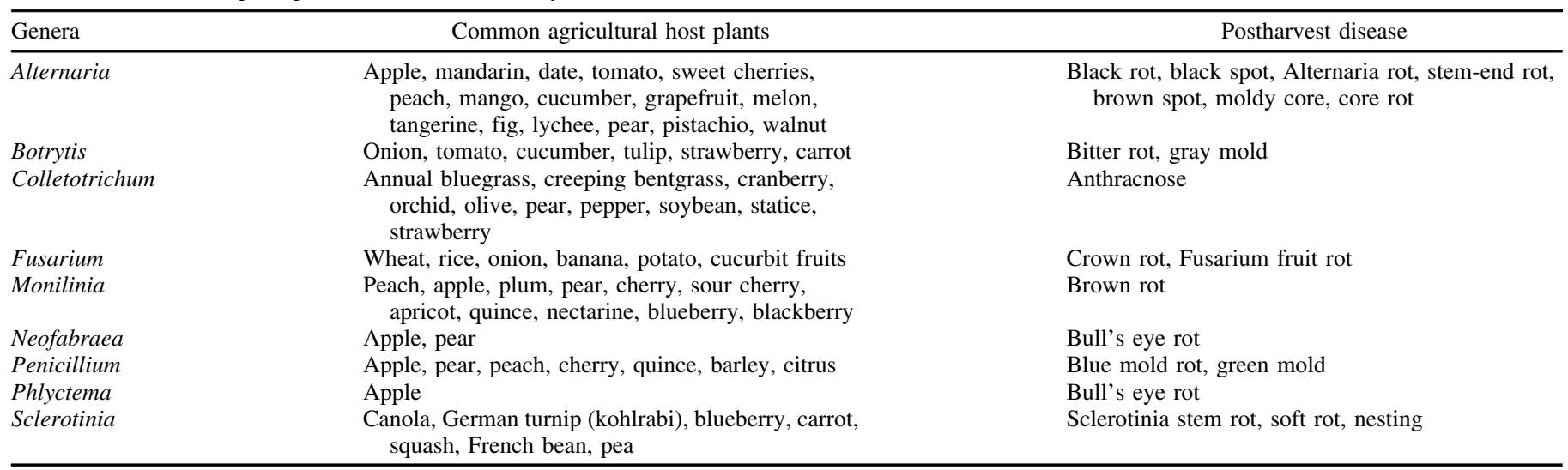


Sequences were filtered using GenBank based on genera and genomic region ( $\beta$-tubulin). All sequences were aligned with the tool Geneious v.11.0.2 (https://www.geneious.com) and the codon 198 position was visually analyzed to infer the genotype of codon position 198 . Any codon 198 genotype that resulted in an amino acid change from glutamic acid was considered a "mutation" in analysis. The GenBank accession number of the obtained sequences were analyzed with the tool BLAST (NCBI) to attain additional information provided by GenBank (i.e., isolate number and occasionally host, region, reference, etc.). The published reference corresponding to each accession number was analyzed to obtain essential information, with email correspondences sent to the publishing author as needed. Additional isolate information from the peer reviewed literature was added to our database for instances where sequences had not been uploaded to GenBank.

The main factors gathered as potential predictive variables for the response variable (amino acid mutation) included the year an isolate was collected, the pathogen genus, the plant host, and the collection region. Data were not included if the authors submitted biased information to GenBank. For example, Sholberg et al. (2005) only reported sequences on isolates that grew on fungicide-selective media. Additionally, oftentimes, authors only sequenced representative phenotypes to evaluate if the $\beta$-tubulin region was associated with resistance (Cosseboom et al. 2019; Yarden and Katan 1993). Isolates were removed if they contained identical isolate numbers and/or we deemed the sequences to be duplicates. We also did not include the majority of full genome sequences and assumed no sequencing errors had occurred.

In the analysis evaluating the amino acid mutation rate over time, time was binned into 5-year periods. In the data where the collection years were reported within a range, we binned the data into the earliest year of the range (if ranges were $>5$ years, we omitted the data).

We also evaluated data based on the different genotypes of codon 198. In this analysis we did not include specimens from the genus Monilinia or the species Fusarium graminearum as their wild-type sequence was glutamic acid (GAA) and we wanted to ascertain the probability of a silent/synonymous mutation from glutamic acid (GAG) to glutamic acid (GAA).

Fungicide usage data collection. FRAC-1 fungicide usage data were collected from California and Arizona, as these are the only localities noted that require users to report their fungicide data. The data included the total active ingredients used and total acreage on which FRAC-1 fungicides were applied. As California and Arizona consist of such a large fraction of agriculture in the United States (USDA 2021), grow a variety of different crops, and have different climates, data from these areas were considered as a "proxy" for worldwide FRAC-1 fungicide usage over time. In California, data quality before 1990 is less certain, as error-checking procedures that are currently in place were not then in effect. Additionally, full-use reporting did not become a requirement until 1990 (Crump et al. 2018; Farrar et al. 2016). In Arizona, growers are not required to report $100 \%$ of all pesticide uses, but they must report all forhire applications, which tend to represent a significant portion, if not a majority (Fournier et al. 2007), of all pesticide applications in the state. Data on the total amount of acreage on which FRAC-1 fungicides were applied were obtained, as this could be a better indication of fungicide usage over time with active ingredient-recommended rates changing as products become more efficient.

Statistical analysis. As the response variable (amino acid mutation) was binary (yes/no), statistical analyses were done using a logistic regression in the software $\mathrm{R}$ v.3.31 (R Core Team 2017) to evaluate the association between an amino acid mutation with the year an isolate was collected, the pathogen genus, the host, and the collection region. The predictor variables were evaluated individually and in a model that accounted for interaction effects. Multicollinear predictor variables were not used in the same model. For example, host and pathogen were not used in the same model as certain hosts are often correlated with certain pathogen genera. Models were followed by a $\chi^{2}$ test to evaluate predictor variable significance.

\section{RESULTS}

In total, data were acquired from 2,647 specimens from GenBank and from 203 references from around the world (Supplementary Table S1). Data were obtained for the pathogen species, plant host, year the specimen was isolated, and the locality of the collection. The specimens consisted of data from 53 countries, on >200 hosts collected between the years 1926 and 2020. Results were nearly identical between the two models, as well as when the variables were analyzed individually. All predictor variables (host, locality, pathogen genus, and time) were significantly $(P<0.05)$ associated with the mutation in all models and when they were analyzed individually.

Genotype frequency. In total, $15.34 \%$ of the specimens evaluated contained an amino acid mutation differing from the GAG wild-type codon in position 198 of the of $\beta$-tubulin region (Table 3 ). The genotype frequencies of codon position 198 differed substantially, with GAG (84.88\%; glutamic acid) being the most common genotype. GCG, coding for alanine, was the second most common, with a frequency of $12.24 \%$. All other genotypes, including the silent/synonymous mutation GAA, occurred at frequencies $<1 \%$.

Mutation frequency by year. The dataset evaluating the association between collection year and amino acid 198 mutation frequency included a total of 1,754 specimens. Fifty-six samples were sequenced that were collected before 1986 (none contained a mutation). The first sequence that contained a mutation in our dataset was from Colletotrichum gloeosporioides on wild strawberry (Fragaria vulgaris) from 1986 in the United States (GenBank accession number DQ522504). The years 2005 to 2009 had the highest frequency of an amino acid mutation (29.78\%), followed by 2000 to 2004 (20.23\%) and 2010 to $2014(17.63 \%)$. Mutations were seen in all time periods evaluated after 1980 to 1984 (Fig. 1). Sample sizes of $\beta$-tubulin sequences tended to increase over time. Between 1985 and 1989, the sample size of $\beta$-tubulin sequences was 12, followed by 43 between 1990 and 1994, 83 between 1995 and 1999, 173 between 2000 and 2004, 188 between 2005 and 2009, 744 between 2010 and 2014, and 531 between 2015 and 2020. In statistical analysis with collection year as a predictor variable, collection year is significantly associated with an amino acid mutation $(P<0.001)$. The years 2005 to 2009 had the lowest $P$ value $(P<0.001)$, followed by 2000 to 2004 and 2010 to $2014(P<0.05)$.

Fungicide usage over time. FRAC-1 fungicide usage in California and Arizona depicted similar patterns where FRAC-1 active ingredients' usage started to decline between 1995 and 2005 (Fig. 2). In Arizona, the pounds of FRAC-1 active ingredients used peaked in 2003 at 3,990 pounds and has been steadily decreasing since. In California, the pounds of FRAC-1 active ingredients peaked in 1998 at 435,232 pounds. The total amount of acreage treated with FRAC-1 fungicides peaked in Arizona in 1997 at 11,567 acres, and in California in 1999 at 612,609.37 acres.

Mutation frequency by pathogen genus. An amino acid mutation was significantly associated with pathogen genus $(P<0.001)$. Data using pathogen genus as a predictor variable are presented in Figure 3. Thirty-four different species were found to have a mutation (Table 4). No mutations were noted in Aspergillus $(n=58)$, Coleophoma $(n=5)$, and Pezicula $(n=81)$. The genera with the highest amino acid 198 mutation frequencies were Colletotrichum (34\%)

TABLE 3. Genotype frequency of the $\beta$-tubulin 198 codon position of the specimens evaluated in this study

\begin{tabular}{lrl}
\hline Genotype & Frequency $(\%)$ & Amino acid \\
\hline GAG & 84.88 & Glutamic acid \\
GAA & 0.45 & Glutamic acid \\
GCG & 12.24 & Alanine \\
AAG & 0.93 & Lysine \\
GTG & 0.69 & Valine \\
CAG & 0.77 & Glutamine \\
GAT & 0.04 & Aspartate \\
\hline
\end{tabular}


and Botrytis (25.46\%). The association between an amino acid 198 mutation and fungicide resistance differed based upon the pathogen species/genus (Table 4). For example, the mutation in Botrytis cinerea is close to 100\% correlated with fungicide resistance (Cai et al. 2015; Cosseboom et al. 2019; Yarden and Katan 1993), whereas the mutation in Penicillium tends to be associated with resistance $<70 \%$ of the time (Baraldi et al. 2003; Cabañas et al. 2009; Sholberg et al. 2005).

Mutation frequency by host. The dataset evaluating the frequency of the association between the host source and amino acid 198 mutation frequency included a total of 2,377 specimens. Host was significantly associated with isolates containing the mutation

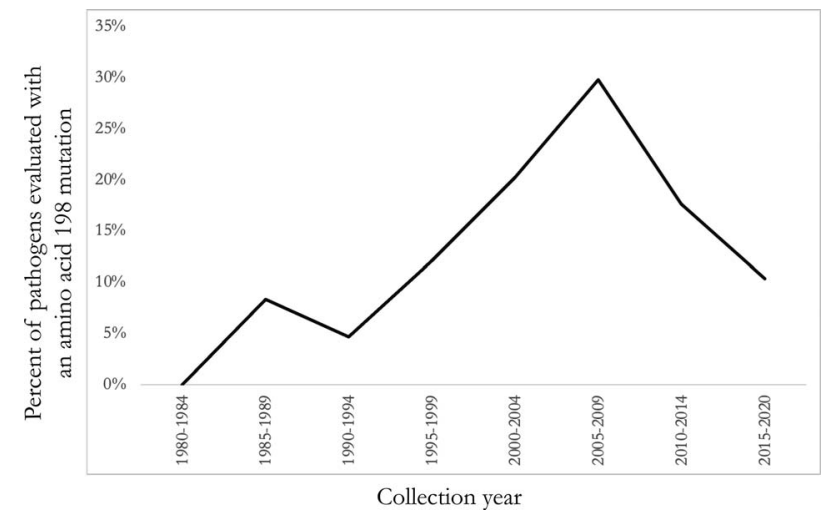

Fig. 1. Percent of pathogens evaluated harboring an amino acid 198 mutation over the past 40 years.
$(P<0.001)$ (Fig. 4). In total, $>36$ different hosts had fungal pathogens that contained an amino acid mutation in position 198 (Table 5). Blueberry, nectarine, pea, and raspberry were not included in Figure 4 or Table 5 because of their low sample size $(n<10)$; however, they were all significantly associated with fungi that possessed this mutation $(P<0.05)$. Peppers $(95.6 \%)$ and soybeans $(84.2 \%)$ had the highest frequency. Statice and peppers had the lowest $P$ values $(P<0.001)$ in statistical analysis; however, the majority of data from these two hosts came from two studies: one in Israel evaluating C. gloeosporioides on Statice (Maymon et al. 2006), and one from Trinidad and Tobago evaluating Colletotrichum truncatum on peppers (Ramdial et al. 2016).

Mutation frequency by locality. The dataset evaluating the association between collection locality and amino acid 198 mutation frequency included a total of 2,511 specimens. Raw data from all of the countries $(n>10)$ evaluated in this study are presented in Table 6 . The mutation was found in 24 countries from all continents, with the exceptions of Africa and Antarctica (Fig. 5). The sample size in Africa was small $(n=3)$, so no definite conclusions can be made on its presence/absence. The following countries were significantly associated with the mutation $(P<0.05)$ : Argentina, Brazil, Canada, Chile, China, France, India, Iran, Israel, South Korea, Taiwan, and the United States. Regions that are statistically associated with the mutation tend to harbor specimens that have a higher mutation frequency. A lower $P$ value, for a certain region, often has a higher mutation frequency in their population whereas insignificant regions tend to have lower mutation frequencies. All of the specimens from Trinidad and Tobago $(n=87)$ contained the mutation.

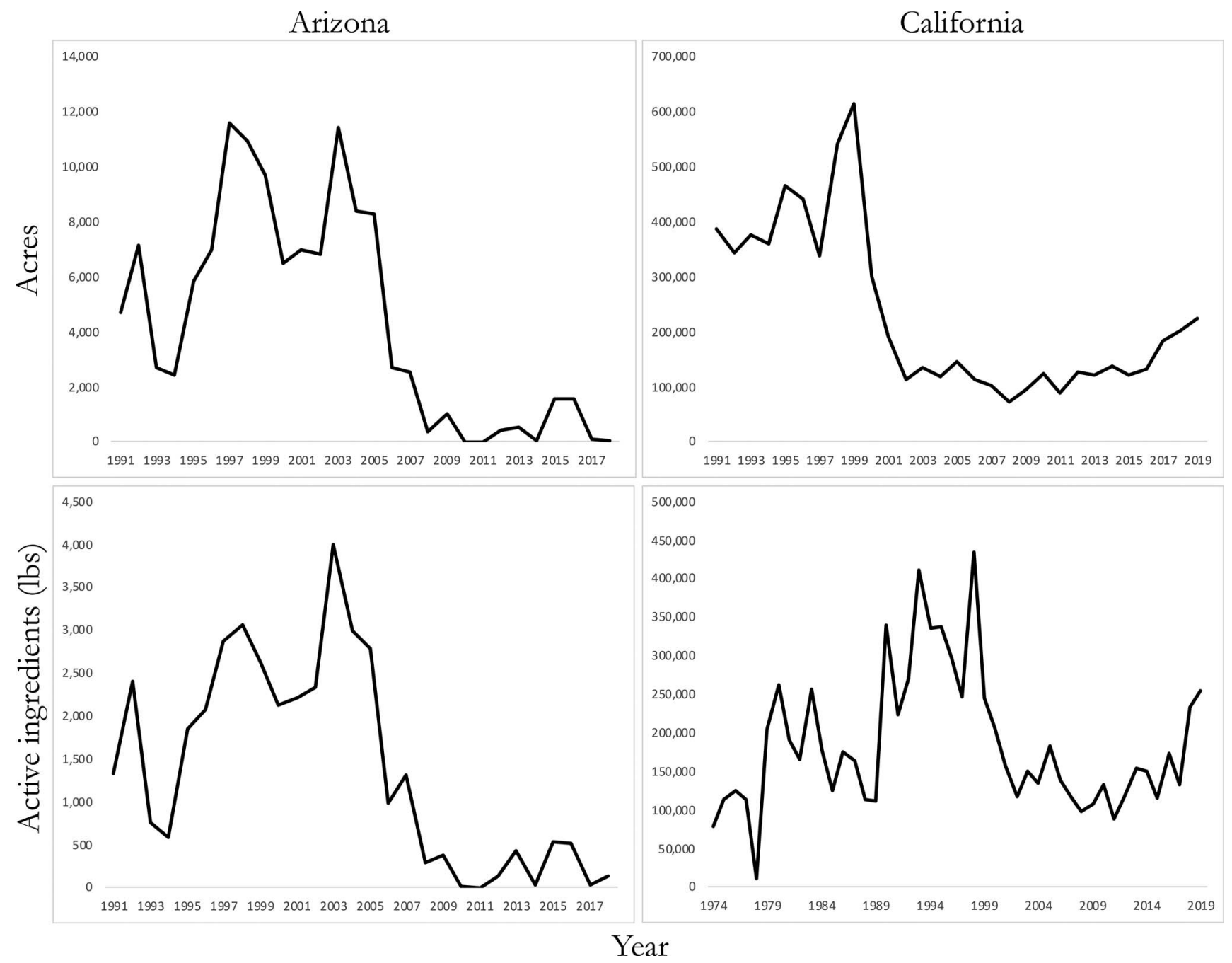

Fig. 2. Fungicide Resistance Action Committee-1 fungicide usage over time in California and Arizona presented as total pounds of active ingredients applied and acres treated. 


\section{DISCUSSION}

Fungicide resistance of several postharvest fungal pathogens was evaluated from around the world on a range of hosts within the last 90 years, to infer temporal, spatial, species, and host patterns of fungicide resistance. Statistical analyses showed that fungicide resistance (measured as a proxy of a mutation in the $\beta$-tubulin amino acid 198 position) is significantly associated with time of isolate collection, the pathogen genus, the pathogen host, and the collection locality.

The amino acid mutation frequency in this study (Table 3 ) is likely an underestimate of the actual percent of the population that is resistant to FRAC-1 fungicides. For example, in multiple systems, the pathogen can be resistant if it carries the 198 or the 200 mutation (Chen et al. 2013; Lee et al. 2011; Young et al. 2010) and resistance based on a mutation in amino acid position 200 would not have been calculated into the data presented. However, the amino acid 200 position is not highly associated with resistance (Chung et al. 2010; Sholberg et al. 2005). Additionally, low to moderately resistant strains often do not contain an amino acid mutation (Chen et al. 2009; Chung et al. 2006; Ma et al. 2003; Yarden and Katan 1993; Ziogas et al. 2009), and thus, our data may only correspond to "highly resistant" isolates that coincide with practical resistance (e.g., failure of a given product to control a specific pathogen). On the contrary, it is possible we are overestimating the true frequency, as it has been reported that sensitive isolates can also contain the mutation; indeed, Adnan et al. (2018) found that $2 / 10$ sensitive B. cinerea isolates contained a 198 amino acid mutation.

Although multiple mutations (synonymous and nonsynonymous) in the 198 codon are known to be associated with FRAC-1 fungicide resistance (Koenraadt et al. 1992), there are large differences in the population frequency of the different mutations (Table 3). The different genotypic frequencies are likely to be from discrepancies in the fitness costs of the different amino acid 198 mutations. The E198A mutation is the most prevalent mutation in the population $(12.24 \%)$ and thus, fitness cost is likely less than the other mutations. Baraldi et al. (2003) found that resistant Penicillium expansum isolates had a higher infection severity on fruits and produced larger lesions than sensitive isolates.

There has been a decline in fungicide usage (Fig. 2), which has likely contributed to the decline in the worldwide 198 mutation frequency (Fig. 1). Fungicide resistance frequency tends to follow fungicide usage after $\sim 5$ to 10 years. We hypothesize that the quick decline in resistance in response to reduced selection pressure is indicative of the mutation having a previously uncharacterized fitness cost. Our hypothesis is contrary to previous research that noted that there was no fitness cost via the 198 mutation. However, research evaluating fitness of pathogenic fungi tends to be accomplished mainly in laboratory settings and under controlled conditions (Baraldi et al. 2003; Ziogas et al. 2009). In a laboratory setting, ecological factors that impact fitness can be overlooked. For example, there could be an effect of the mutation on its ability to withstand harsh environmental conditions, spread by wind, or on its competitive fitness to interact with the consortium of microbes that live on the viable host. In the future, if FRAC-1 fungicide applications continue to decline, we expect fungicide resistance will decline and thus result in an increase in FRAC-1 fungicide efficacy. However, as seen from California (Fig. 2), FRAC-1 usage seems to be gaining popularity within the past 5 years, and in the future an increase in FRAC-1 resistance is expected. It should also be noted that the fitness cost/benefit of an E198A mutation may be species dependent, and this has yet to be explored in natural settings.

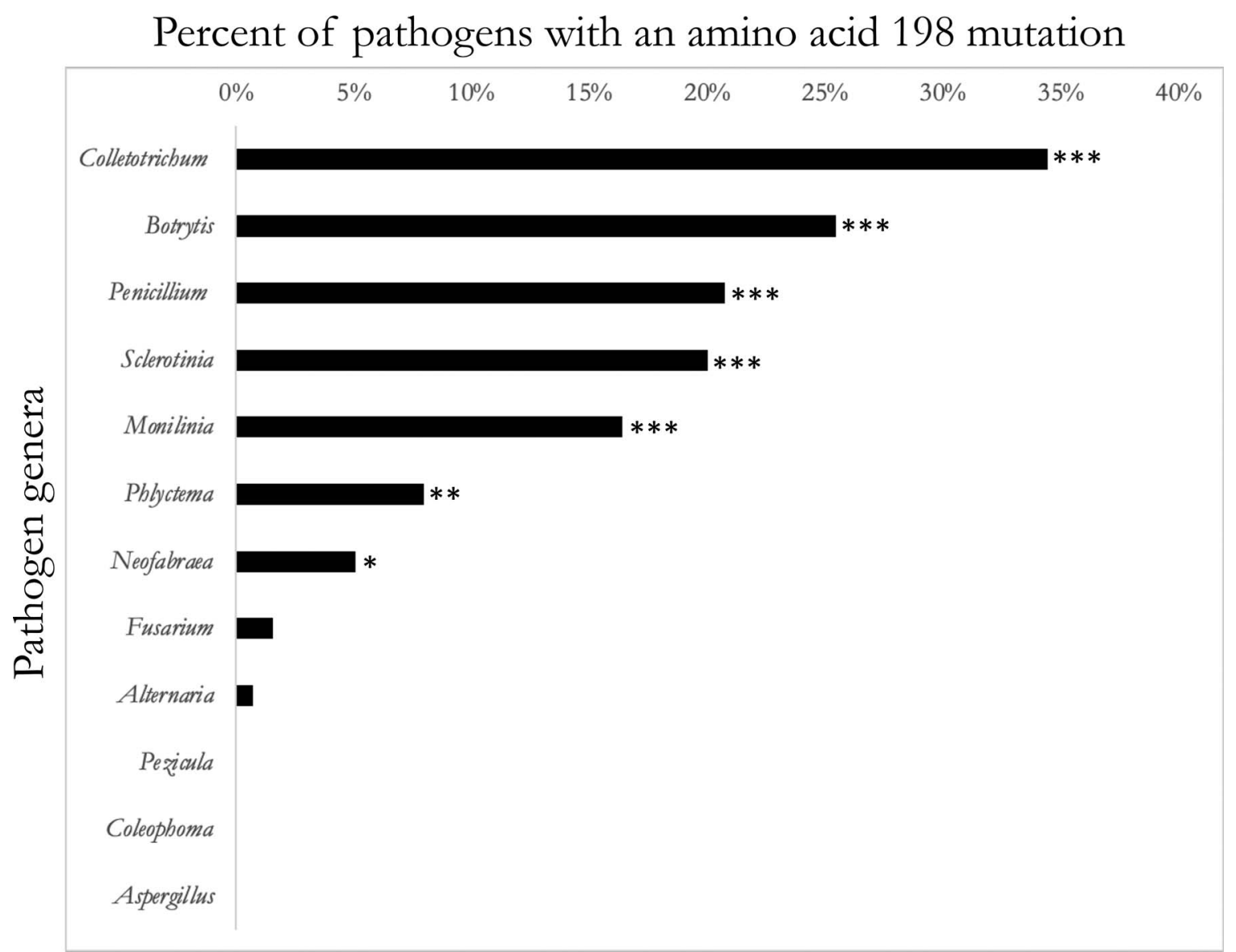

Fig. 3. Bar graph showing the percent of each postharvest pathogen genus evaluated that contained an amino acid 198 mutation. There is a statistically significant association in a logistic regression analysis between the host and the resistant mutation. ${ }^{*} P<0.05 ; * * P<0.01$; and ${ }^{* * *} P<0.001$. 
The first sequence containing a 198 mutation was from a $C$. gloeosporioides specimen collected from wild strawberry ( $F$. vulgaris) in 1986. As resistance to FRAC-1 fungicides was reported in the late 1960s (Schroeder and Provvidenti 1969), we believe the mutation was present in higher levels in the 1970s and 1980s than reported in this study, as we were limited by a small sample size $(n=22$ in the 1970s and $n=20$ in the 1980s). The C. gloeosporioides specimen from 1986 on wild strawberry provides evidence for this claim; fungicides are not applied on wild strawberries, thus, the pathogen must have been prevalent in the population, and have come from a nearby, heavily sprayed, strawberry field or, less likely, was a stochastic event that resulted in its presence without fungicide pressure. Therefore, it is probable that, by 1986, resistant genotypes of $C$. gloeosporioides, and possibly other pathogens, were already established and prevalent

TABLE 4. Amino acid 198 mutation frequency of different postharvest pathogen species and genera evaluated in this study

\begin{tabular}{|c|c|c|c|c|c|c|}
\hline Species $^{\mathrm{a}}$ & $N$ & $\begin{array}{l}\text { Isolates with a } \\
\text { mutation, \% }\end{array}$ & $\begin{array}{l}\text { Most prevalent host } \\
\text { associated with a } \\
\text { mutation }\end{array}$ & $\begin{array}{c}\text { Most prevalent } \\
\text { location associated } \\
\text { with a mutation }\end{array}$ & $\begin{array}{c}\text { Resistant isolates } \\
\text { that contain a } \\
\text { mutation, } \%\end{array}$ & References \\
\hline Total & 2,647 & 15.34 & & & & \\
\hline Alternaria & 271 & 0.74 & & & & \\
\hline Alternaria alternata & 108 & 1.85 & Date & & & \\
\hline Botrytis & 221 & 25.46 & & & & \\
\hline Botrytis acalada & 4 & 25 & Onion & New Zealand & & \\
\hline Botrytis cinerea & 158 & 39.87 & Grape & France & 100 & $\begin{array}{l}\text { Adnan et al. }(2018)^{\mathrm{b}} ; \\
\text { Cai et al. (2015); } \\
\text { Cosseboom et al. (2019); } \\
\text { Yarden and Katan (1993) }\end{array}$ \\
\hline Botrytis fragariae & 2 & 50 & Strawberry & Germany & & \\
\hline Botrytis squamosa & 27 & 11 & Onion & Canada & & \\
\hline Botrytis tulipiae & 4 & 25 & Tulip & Canada & & \\
\hline Colletotrichum & 705 & 34.75 & & & & \\
\hline Colletotrichum acutatum & 8 & 25 & $\begin{array}{l}\text { Strawberry and } \\
\text { grape }\end{array}$ & Japan & 0 & Chung et al. $(2006)^{\mathrm{d}}$; \\
\hline Colletotrichum cereale & 62 & 41.93 & Creeping bentgrass & United States & 60.87 & Young et al. (2010) \\
\hline Colletotrichum cliviae & 1 & 100 & Orchid & India & & \\
\hline Colletotrichum cymbidiicola & 11 & 63.64 & Orchid & India & & \\
\hline Colletotrichum fruticola & 25 & 4 & Strawberry & & & \\
\hline $\begin{array}{l}\text { Colletotrichum } \\
\text { gloeosporioides }\end{array}$ & 141 & 45.39 & Statice & Israel & 100 & $\begin{array}{l}\text { Chung et al. (2006) }{ }^{\mathrm{d}} \text {; } \\
\text { Maymon et al. (2006) }\end{array}$ \\
\hline Colletotrichum musicola & 1 & 100 & Soybeans & Brazil & & \\
\hline Colletotrichum plurivorum & 15 & 100 & Soybeans & Brazil & & \\
\hline Colletotrichum siamense & 115 & 33.91 & Strawberry & United States & 100 & Martin et al. (2021) \\
\hline Colletotrichum truncatum & 89 & 97.75 & Peppers & $\begin{array}{l}\text { Trinidad and } \\
\text { Tobago }\end{array}$ & & \\
\hline Fusarium & 707 & 1.56 & & & & \\
\hline Fusarium asiaticum & 13 & 7.69 & & & & \\
\hline Fusarium fujikuroi & 67 & 1.49 & Rice & China & & \\
\hline Fusarium graminearum & 77 & 9.09 & Wheat & China & 100 & Chen et al. $(2009)^{\mathrm{e}}$ \\
\hline Fusarium oxysporum & 473 & 0.21 & $\begin{array}{l}\text { Ctenanthe } \\
\text { oppenheimiana }\end{array}$ & China & & \\
\hline Fusarium proliferatum & 76 & 1.30 & Onion & United Kingdom & & \\
\hline Monilinia & 73 & 16.40 & & & & \\
\hline Monilinia fructicola & 62 & 19.35 & Peach & United States & $31.8,100$ & $\begin{array}{l}\text { Chen et al. (2013); } \\
\text { Ma et al. (2003); } \\
\text { Martini et al. (2016) }\end{array}$ \\
\hline Neofabraea & 138 & 5.07 & Apple & & & \\
\hline Neofabraea actinidiae & 8 & 37.50 & & & & \\
\hline Neofabraea brasiliensis & 3 & 100 & & & & \\
\hline Neofabraea perennans & 33 & 3.03 & & & & \\
\hline Penicillium & 212 & 20.75 & & & & \\
\hline Penicillium albocoremium & 1 & 100 & & & & \\
\hline Penicillium commune & 1 & 100 & Apple & Canada & & \\
\hline Penicillium cyclopium & 1 & 100 & Barley & Denmark & & \\
\hline Penicillium digitatum & 40 & 45 & Orange & Taiwan & 48.65 & Lee et al. (2011) \\
\hline Penicillium expansum & 104 & 16.34 & Apple/pear & Spain & $23.5,50,66.67$ & $\begin{array}{l}\text { Baraldi et al. (2003); } \\
\text { Cabañas et al. (2009); } \\
\text { Sholberg et al. (2005) }\end{array}$ \\
\hline Penicillium italicum & 1 & 100 & Air & & & \\
\hline Penicillium solitum & 5 & 100 & & Canada & 100 & Sholberg et al. (2005) \\
\hline Phlyctema & 163 & 7.98 & & & & \\
\hline Phlyctema vagabunda & 162 & 8.02 & Apple & Chile & & \\
\hline Sclerotinia & 15 & 20 & & & & \\
\hline Sclerotinia sclerotiorum & 14 & 21.42 & Canola & China & & \\
\hline
\end{tabular}

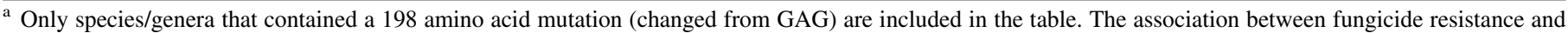
an amino acid 198 mutation of each species was determined from previous studies.

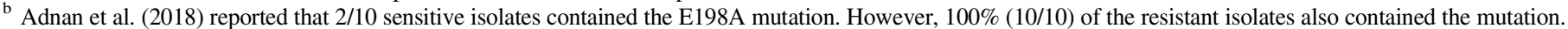

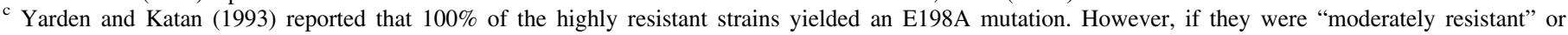

"sensitive," they did not contain a mutation.

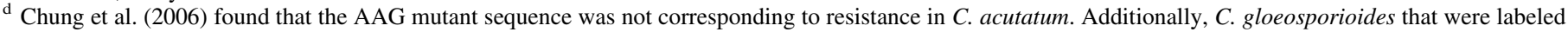
as "intermediately resistant" did not contain the E198A mutation. However, all "highly resistant" strains contained the mutation.

e Chen et al. (2009) determined that $100 \%$ of the highly resistant isolates contained a mutation. However, none of the "moderately resistant" isolates did.

f Ma et al. (2003) reported that $100 \%$ of the highly resistant isolates had the mutation. However, none of the "low resistant" isolates had the mutation. 
throughout the United States. Since 1986, the frequency of the mutation in the population increased to a maximum of $29.78 \%$ between the years 2005 and 2009. After 2009, the mutation frequency proceeded to decline to $17.61 \%$ between 2010 and 2014 and then to $10.36 \%$ between 2015 and 2020 (Fig. 1). This may be caused by many factors, but one of the most obvious contributors could have been less usage of the FRAC-1 material, in lieu of other site-specific MOA chemistries including the demethylation inhibitors (FRAC 3), strobilurins (FRAC 11), and limited multisite materials such as Ziram and Captan (FRAC M).

The overall pattern of increased FRAC-1 fungicide resistance from the 1990s to the 2000s (Fig. 1) agrees with data from previous studies on multiple systems. For example, $25.64 \%$ of Monilinia fructicola collected between 1994 and 2002 on stone fruits were highly resistant to FRAC-11 fungicides (Ma et al. 2003); however, $73.02 \%$ of $M$. fructicola isolates collected in 2011 were resistant (Martini et al. 2016). Additionally, in a 3-year survey from 1991 to 1993, Sholberg and Haag (1996) found $22.9 \%$ of Penicillium spp. isolates to be resistant, whereas $52 \%$ of isolates collected in 2004 to 2005 were found to be resistant (Cabañas et al. 2009).

The decreasing frequency of the resistance mutation and fungicide usage (Fig. 1) can likely be attributed to the implementation of IPM strategies and fungicide resistance programs implemented by farmers. After the peak resistance frequency observed between 2005 and 2009 (29.78\%), IPM strategies, such as rotating fungicides with different MOAs, could have been successful in combating or minimizing resistance. Additionally, FRAC-11 fungicides, such as quinone outside inhibitors, have gained popularity because of their high efficacy (Moparthi and Bradshaw 2020). The popularity and success of FRAC-11 fungicides, coupled with the fitness cost of a 198 mutation, is likely contributing to the decline in FRAC-1 fungicide usage and resistant fungal populations. We hypothesize that in the future, resistance will follow an oscillating pattern as fungicides continue to be rotated.

Pathogen genus is also significantly associated with resistance, and there is substantial variation among genera (Fig. 3). Botrytis, Colletotrichum, Monilinia, Neofabraea, Phlyctema, and Penicillium were significantly associated with $\beta$-tubulin amino acid 198 mutations, with Colletotrichum and Botrytis having the highest mutation frequency (Fig. 3). Also, there is a considerable amount of interspecies variation in the mutation frequency (Table 3). A possible contributor to this phenomenon is that the correlation between a codon 198 mutation and the resistance phenotype differs based upon species (Table 2). For example, Chung et al. (2006) and Nakaune and Nakano (2007) both reported that codon 198 mutations in Colletotrichum acutatum are not associated with resistance, whereas in multiple other species within this genus, there is a high association between the mutation

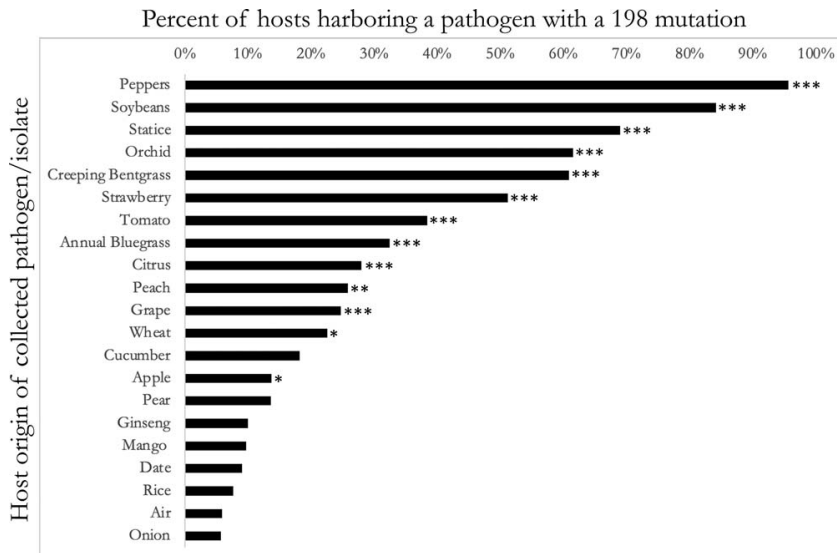

Fig. 4. Bar graph showing the percent of postharvest pathogens evaluated on each host that contained an amino acid 198 mutation. There is a statistically significant association in a logistic regression analysis between the host and the presence of the resistant mutation. ${ }^{*} P<0.05$; ${ }^{* *} P<0.01$; and ${ }^{*}{ }^{* *} P<$ 0.001 . and resistance (Chung et al. 2006; Martin et al. 2021; Maymon et al. 2006; Young et al. 2010). Future research should evaluate the association between a 198 amino acid mutation and fungicide resistance in a variety of other systems that contain a mutation but have not yet been evaluated, such as the Colletotrichum musicola-soybean and the Colletotrichum cymbidiicola-orchid systems.

Interestingly, no Aspergillus species were noted to carry the 198 mutation in GenBank (Fig. 3). This is unexpected, as multiple authors have reported that mutations in the $\beta$-tubulin region in Aspergillus nidulans confer resistance to FRAC-1 fungicides (Jung and Oakley 1990; Jung et al. 1992; Hastie and Georgopoulos 1971). Possible explanations for this phenomenon (as well as the low frequencies reported for other genera such as Alternaria) include the following:

That fungicides are generally not used on Aspergillus spp., and thus there is no selecting agent for this mutation;

That there is a deleterious effect of an amino acid 198 mutation in Aspergillus spp., which explains why it is nonexistent in the general population;

That these mutations rarely occur in Aspergillus spp. in natural conditions; and/or

That our sample size ( $n=58)$ was too small to identify the mutation by chance.

In reference to the last, possible explanation, silent mutations in the 198 amino acid loci were found to be prevalent at $\sim 0.5 \%$ frequency (Table 3; GAG-GAA), suggesting that we would not have noted the mutation in a sample size of 58. It should be noted that no definite conclusions should be derived when comparing mutations from one site to another, even in the same codon, as the mutation rate varies based on the nucleotide context (Krasovec et al. 2019).

The data reported in this study are generally consistent with the literature, especially in regard to the resistance frequency of the different genera. For example, Chung et al. (2010) found that $41.38 \%$ of C. gloeosporioides isolates evaluated in Taiwan were highly resistant or resistant to FRAC-1 fungicides, whereas we report $45.39 \%$ of C. gloeosporioides isolates contained a $\beta$-tubulin 198 amino acid mutation (Table 3). Additionally, we report a mutation frequency of $21.42 \%$ for Sclerotinia sclerotiorum (Table 2) whereas Wang et al. (2014) reported a $10.13 \%$ resistance frequency among S. sclerotiorum isolates. The differences observed in this study from previous studies can likely be attributed to the locality, host, or conditions in which isolates were collected in any single study. In addition, the possibility of sequencing error needs to be considered by the reader, especially

TABLE 5. Amino acid 198 mutation frequency of different postharvest pathogens based on host species

\begin{tabular}{|c|c|c|c|}
\hline Host $^{\mathrm{a}}$ & $N$ & Mutation, \% & $\begin{array}{l}\text { Most prevalent pathogen } \\
\text { with mutation }\end{array}$ \\
\hline Air & 17 & 5.89 & Penicillium italicum \\
\hline Annual bluegrass & 37 & 32.50 & Colletotrichum cereale \\
\hline Apple & 298 & 13.75 & Penicillium digitatum \\
\hline Creeping bentgrass & 23 & 60.86 & Colletotrichum cereale \\
\hline Cucumber & 22 & 18.18 & Botrytis cinerea \\
\hline Date & 22 & 9.09 & Alternaria alternata \\
\hline Ginseng & 10 & 10 & Botrytis cinerea \\
\hline Grape & 101 & 24.75 & Botrytis cinerea \\
\hline Mango & 82 & 9.76 & Colletotrichum gloeosporioides \\
\hline Onion & 53 & 5.66 & Botrytis spp. \\
\hline Orchid & 13 & 61.53 & Colletotrichum cymbidiicola \\
\hline Peach & 31 & 25.81 & Monilinia fructicola \\
\hline Pear & 22 & 13.64 & Colletotrichum gloeosporioides \\
\hline Peppers & 91 & 95.60 & Colletotrichum truncatum \\
\hline Rice & 13 & 7.69 & Fusarium fujikuroi \\
\hline Soybeans & 19 & 84.20 & Colletotrichum plurivorum \\
\hline Statice & 58 & 69 & Colletotrichum gloeosporioides \\
\hline Strawberry & 82 & 51.22 & Colletotrichum siamense \\
\hline Tomato & 26 & 38.46 & Botrytis cinerea \\
\hline Wheat & 31 & 23 & Fusarium graminearum \\
\hline
\end{tabular}

${ }^{\text {a }}$ Only included if $N>10$ and at least one host contained mutation. 
when there are outliers, as is the case with the one Fusarium oxysporum mutation (GenBank accession no. KX253989) out of the 473 deposited sequences.

The association among fungicide resistance, pathogen host, and geographic region (Fig. 5; Tables 5 and 6) likely stems from the variance in fungicide applications in different regions and on different hosts. Nonetheless, an understanding of the population frequency of resistance throughout the world is important, as fungicide applications may not always be indicative of resistant pathogen populations. For example, fungal pathogens can spread hundreds of miles by wind (Schnathorst 1959), and it should be noted that countries often trade goods that are undoubtedly accompanied by their resistant pathogens.

TABLE 6. Amino acid 198 mutation frequency of different postharvest pathogens based on collection locality

\begin{tabular}{|c|c|c|c|c|}
\hline Location $^{\mathrm{a}}$ & $N$ & Mutation rate, $\%$ & $\begin{array}{l}\text { Most prevalent pathogen } \\
\text { with mutation }\end{array}$ & $\begin{array}{l}\text { Most prevalent host that } \\
\text { contains pathogen with mutation }\end{array}$ \\
\hline Argentina & 12 & 58.33 & Botrytis cinerea & Strawberry \\
\hline Australia & 127 & 0 & & \\
\hline Brazil & 112 & 19.64 & Colletotrichum plurivorum & Soybean \\
\hline Canada & 107 & 18.6 & Penicillium expansum & Apple \\
\hline Chile & 72 & 15.23 & Phlyctema cinerea & Apple \\
\hline China & 317 & 11.08 & Botrytis cinerea & Wheat and strawberry \\
\hline Colombia & 88 & 0 & & \\
\hline Denmark & 12 & 8.33 & Penicillium cyclopium & Barley \\
\hline France & 53 & 43.40 & Botrytis cinerea & Grape \\
\hline Germany & 22 & 9.09 & Botrytis spp. & Strawberry \\
\hline Hungary & 14 & 21.42 & Botrytis cinerea & Raspberry \\
\hline India & 20 & 40 & Colletotrichum cymbidiicola & Orchid \\
\hline Iran & 30 & 30 & Botrytis cinerea & Grape \\
\hline Israel & 65 & 61.54 & Colletotrichum gloeosporioides & Statice \\
\hline Italy & 121 & 2.50 & Monilinia fructicola & Grape, nectarine, peach \\
\hline Japan & 78 & 6.41 & Colletotrichum gloeosporioides & Pear \\
\hline Malaysia & 52 & 0 & & \\
\hline Mexico & 13 & 0 & & \\
\hline The Netherlands & 23 & 4.35 & & \\
\hline New Zealand & 33 & 6.06 & Botrytis spp. & Grape and onion \\
\hline Pakistan & 20 & 5 & Colletotrichum gloeosporioides & Strawberry \\
\hline Poland & 91 & 1.10 & Phlyctema vagabunda & Apple \\
\hline Serbia & 15 & 0 & & \\
\hline South Korea & 10 & 40 & Colletotrichum gloeosporioides & Apple \\
\hline Spain & 115 & 7 & Penicillium expansum & Apple/pear \\
\hline Taiwan & 48 & 35.42 & Penicillium digitatum & Orange \\
\hline Trinidad and Tobago & 87 & 100 & Colletotrichum truncatum & Peppers \\
\hline Turkey & 12 & 0 & & \\
\hline United Kingdom & 51 & 1.96 & Fusarium proliferatum & Onion \\
\hline United States & 591 & 12.52 & Colletotrichum siamense & Strawberry \\
\hline
\end{tabular}

${ }^{\text {a }}$ Only included if $N>10$.

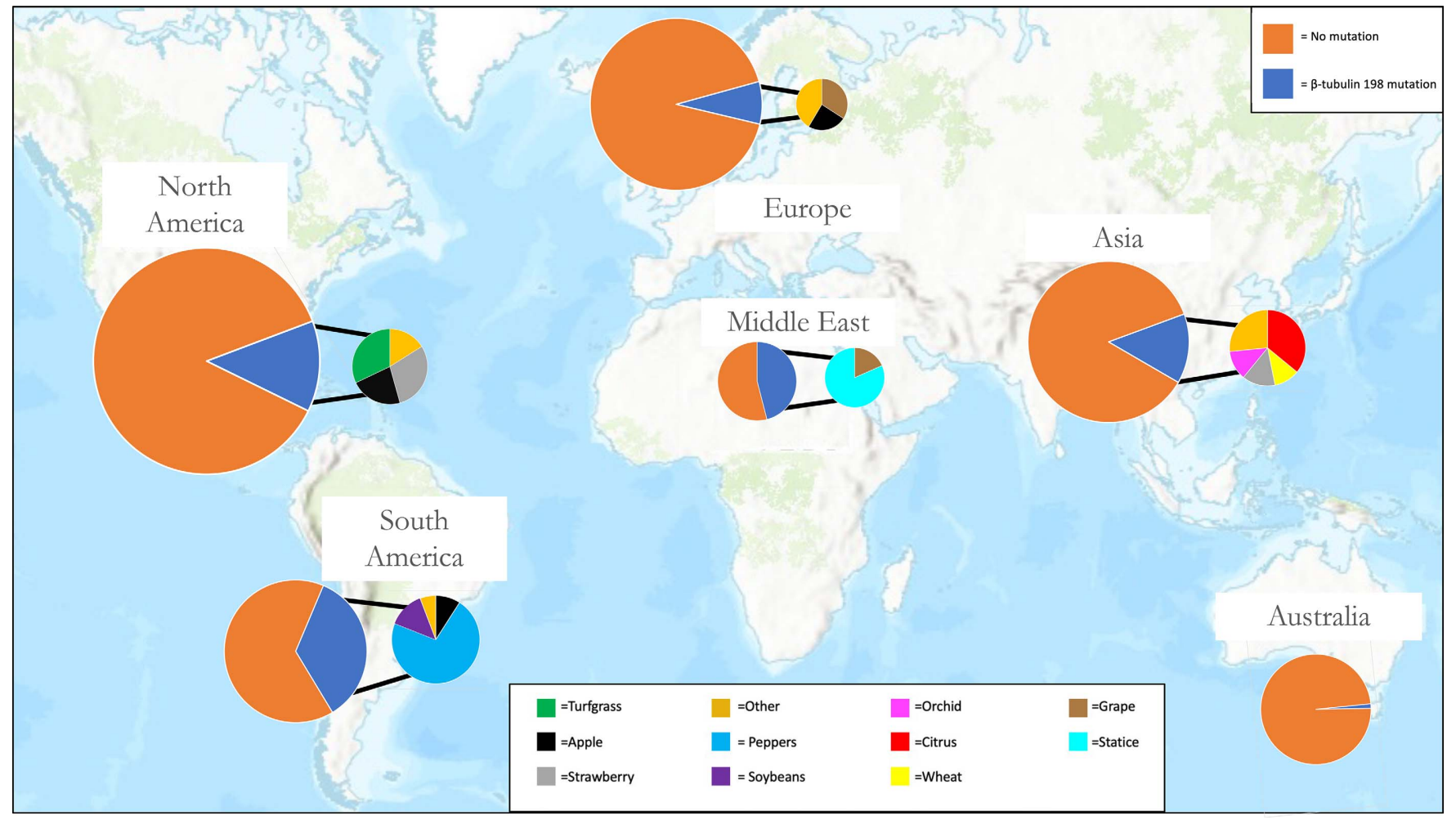

Fig. 5. Amino acid 198 mutation frequency based on the collection region and the pathogen host. 
Maymon et al. (2006) found high amounts of $C$. gloeosporioides that were resistant to FRAC-1 fungicides in Israel on statice even though FRAC-1 fungicides were never reported on this crop in this region, and Cosseboom et al. (2019) reported $72 \%$ of $B$. cinerea from organic strawberry fields in California were resistant to FRAC-1 fungicides. In the California strawberry industry, nurseries that grow transplants for the organic industry apply fungicides and thus, are likely spreading resistant populations to organic operations.

Similar to previous studies (Cosseboom and $\mathrm{Hu} 2021$; Johnson et al. 1994), we noticed differences in resistance based on host (Fig. 4). Peppers, soybeans, statice, and orchids had isolates containing the highest mutation frequency (Table 5). Of course, our data have some internal biases and are likely underrepresented/skewed in some areas/hosts and overrepresented/skewed in others. Cosseboom et al. (2019) and Johnson et al. (1994) reported that $>75 \%$ of $B$. cinerea on strawberries contained the resistance mutation; however, in our study, $48.72 \%$ of pathogens collected from strawberries contained the resistant loci. The surveys by Cosseboom et al. (2019) and Johnson et al. (1994) were both accomplished in the Western United States, where high amounts of fungicides are used in the strawberry industry.

Additionally, the high amount of the resistance mutations we noted on peppers is most likely not indicative of the worldwide population; the majority of these data came from one study (i.e., Ramdial et al. 2016). However, these data should not be discounted. Ramdial et al. (2016) evaluated peppers from Trinidad and Tobago, and sequenced 87 isolates of $C$. truncatum, all of which were resistant to FRAC-1 fungicides and contained an amino acid 198 mutation.

The resistance genotype located on soybeans from Brazil (Boufleur et al. 2020) and orchids from India (Chowdappa et al. 2014) are both worth mentioning, although neither of the studies that reported these genotypes were evaluating fungicide resistance. We hypothesize that soybeans from Brazil and orchids from India are highly resistant to FRAC-1 fungicides, and that future research should evaluate fungicide resistance on both of these crops in those localities. Countries that depend on soybeans and have large orchidgrowing productions should screen incoming crops for fungicideresistant pathogens.

As the trading of goods results in the movement of fungicideresistant pathogens (Maymon et al. 2006), growers of certain products need to be aware of the potential harm of using FRAC-1 fungicides and consider alternative control methods. This study was conducted as a resource for countries and farmers that are reliant on FRAC-1 fungicides for the control of postharvest pathogens. Using the presented data, screenings should be implemented when crops from regions/hosts with high levels of resistance are exchanged. Future research can use the data compiled in this study (Supplementary Table S1) to make inferences on the amount of FRAC-1 fungicides used, the probability and speed at which resistance builds up, and generate models to predict the movement of resistance through space and time. Additionally, our study provides a platform to translate our methodology of analysis to other MOA chemistries that have tightly correlated resistance mutations (e.g., azoles and CYP51A1, and G143A for strobilurins) to determine similar trends, patterns, and predictive models for assessing risk of developing resistance.

\section{ACKNOWLEDGMENTS}

We thank the Canadian National Mycological Herbarium and the Agricultural Research Service's Culture Collection for providing information on many specimens; and Kimberly Steinmann from the California Department of Pesticide Regulation and Alfred Fournier, Peter Ellsworth, and Wayne Dixon from the Arizona Pest Management Center, University of Arizona, for supplying the fungicide usage data. All opinions expressed in this paper are the authors' and do not necessarily reflect the policies and views of the U.S. Department of Agriculture, the Department of Energy, the Oak Ridge Associated Universities, or the Oak Ridge Institute for Science and Education. Mention of trade names or commercial products in this publication is solely for providing specific information and does not imply recommendation or endorsement by the U.S. Department of Agriculture.

\section{LITERATURE CITED}

Adnan, M., Hamada, M. S., Li, G. Q., and Luo, C. X. 2018. Detection and molecular characterization of resistance to the dicarboximide and benzamide fungicides in Botrytis cinerea from tomato in Hubei Province, China. Plant Dis. 102:1299-1306.

Agrios, G. N. 2005. Pesticides and plant diseases. Page 69 in: Plant Pathology, 5th Ed. Elsevier Academic Press, Burlington, MA.

Atwood, D., and Paisley-Jones, C. 2017. Pesticide Industry Sales and Usage 2008-2012 Market Estimates. U.S. Environmental Protection Agency, Washington, DC. https://www.epa.gov/sites/production/files/2017-01/documents/pesticides-industry-sales-usage-2016_0.pdf

Banno, S., Fukumori, F., Ichiishi, A., Okada, K., Uekusa, H., Kimura, M., and Fujimura, M. 2008. Genotyping of benzimidazole-resistant and dicarboximide-resistant mutations in Botrytis cinerea using real-time polymerase chain reaction assays. Phytopathology 98:397-404.

Baraldi, E., Mari, M., Chierici, E., Pondrelli, M., Bertolini, P., and Pratella, G. C. 2003. Studies on thiabendazole resistance of Penicillium expansum of pears: Pathogenic fitness and genetic characterization. Plant Pathol. 52: 362-370.

Bolay, A., Crettenand, J., Gnaegi, F., and Schopfer, J. F. 1974. The control of grey rot of grapes. Rev. Suisse Vitic. Arboric. Hortic. 6:91-97.

Boufleur, T. R., Castro, R. R. L., Rogério, F., Ciampi-Guillardi, M., Baroncelli, R., and Massola Júnior, N. S. 2020. First report of Colletotrichum musicola causing soybean anthracnose in Brazil. Plant Dis. 104:1858.

Bryk, H. 1997. Appearance and stability of Pezicula alba Gunth. resistant to benzimidazole fungicides. J. Fruit Ornam. Plant Res. 5:77-87.

Buhr, T. L., and Dickman, M. B. 1994. Isolation, characterization, and expression of a second beta-tubulin-encoding gene from Colletotrichum gloeosporioides f. sp. aeschynomene. Appl. Environ. Microbiol. 60:4155-4159.

Cabañas, R., Castellá, G., Abarca, M. L., Bragulat, M. R., and Cabañes, F. J. 2009. Thiabendazole resistance and mutations in the $\beta$-tubulin gene of Penicillium expansum strains isolated from apples and pears with blue mold decay. FEMS Microbiol. Lett. 297:189-195.

Cai, M., Lin, D., Chen, L., Bi, Y., Xiao, L., and Liu, X. L. 2015. M233I mutation in the $\beta$-tubulin of Botrytis cinerea confers resistance to zoxamide. Sci. Rep. 5:16881.

Chen, C. J., Yu, J. J., Bi, C. W., Zhang, Y. N., Xu, J. Q., Wang, J. X., and Zhou, M. G. 2009. Mutations in a $\beta$-tubulin confer resistance of Gibberella zeae to benzimidazole fungicides. Phytopathology 99:1403-1411.

Chen, F., Liu, X., and Schnabel, G. 2013. Field strains of Monilinia fructicola resistant to both MBC and DMI fungicides isolated from stone fruit orchards in the eastern United States. Plant Dis. 97:1063-1068.

Chowdappa, P., Chethana, C. S., Pant, R. P., and Bridge, P. D. 2014. Multilocus gene phylogeny reveals occurrence of Colletotrichum cymbidiicola and $C$. cliviae on orchids in northeast India. J. Plant Pathol. 96:327-334.

Chung, W., Ishii, H., Nishimura, K., Fukaya, M., Yano, K., and Kajitani, Y. 2006. Fungicide sensitivity and phylogenetic relationship of anthracnose fungi isolated from various fruit crops in Japan. Plant Dis. 90:506-512.

Chung, W. H., Chung, W. C., Peng, M. T., Yang, H. R., and Huang, J. W. 2010. Specific detection of benzimidazole resistance in Colletotrichum gloeosporioides from fruit crops by PCR-RFLP. N. Biotechnol. 27:17-24.

Cosseboom, S. D., and Hu, M. J. 2021. Identification and characterization of fungicide resistance in Botrytis populations from small fruit fields in the mid-Atlantic United States. Plant Dis. doi:10.1094/PDIS-03-20-0487-RE.

Cosseboom, S. D., Ivors, K. L., Schnabel, G., Bryson, P. K., and Holmes, G. J. 2019. Within-season shift in fungicide resistance profiles of Botrytis cinerea in California strawberry fields. Plant Dis. 103:59-64.

Crump, A., Farrar, J., Fournier, A. J., and Ellsworth, P. C. 2018. Employing California pesticide use data for evaluating integrated pest management programs and informing pesticide policy and regulation. Pages 225-237 in: ACS Symposium Series, Vol. 1283. American Chemical Society Publications, Washington, DC.

Davidse, L. 1973. Antimitotic activity of methyl benzimidazol-2-yl carbamate (MBC) in Aspergillus nidulans. Pestic. Biochem. Physiol. 3:317-325.

Delp, C. J., and Klopping, H. L. 1968. Performance attributes of a new fungicide and mite ovicide candidate. Plant Dis. Rep. 52:95-99.

Erwin, D. C., Sims, J. J., and Partridge, J. 1968. Evidence for the systemic, fungitoxic activity of 2-(4'-thiazolyl) benzimidazole in the control of Verticillium wilt of cotton. Phytopathology 58:860-865.

Farrar, J. J., Baur, M. E., and Elliott, S. F. 2016. Measuring IPM Impacts in California and Arizona. J. Integr. Pest Manag. 7:13.

Fournier, A. J., Ellsworth, P. C., and Barkley, V. 2007. Economic impact of Lygus in Arizona cotton: a comparative approach. 2007 Cotton Report. Publication No. az1437. College of Agriculture \& Life Sciences, University of Arizona, Tucson, AZ. https://arizona.openrepository.com/handle/10150/198220 
Freeman, J. A., and Pepin, H. S. 1967. A systemic fungicide (Fungicide 1991) for the control of gray mold and powdery mildew in strawberries and raspberries. Can. Plant Dis. Surv. 47:104-107.

Georgopoulos, S. 1969. The problem of fungicide resistance. Bioscience 19: 971-973.

Harding, Jr., P. R. 1959. Diphenyl-induced variations in citrus blue mold. Plant Dis. Rep. 43:649-653.

Hastie, A. C., and Georgopoulos, S. G. 1971. Mutational resistance to fungitoxic derivative in Aspergillus nidulans. J. Gen. Microbiol. 67:371-373.

Johnson, K. B., Sawyer, T. L., and Powelson, M. L. 1994. Frequency of benzimidazole-resistant and dicarboximide-resistant strains of Botrytis cinerea in western Oregon small fruit and snap bean plantings. Plant Dis. 78:572-577.

Jones, A. L., and Walker, R. J. 1976. Tolerance of Venturia inaequalis to dodine and benzimidazole fungicides in Michigan. Plant Dis. Rep. 60:40-44.

Jung, M. K., and Oakley, B. R. 1990. Identification of an amino acid substitution in the benA, $\beta$-tubulin gene of Aspergillus nidulans that confers thiabendazole resistance and benomyl supersensitivity. Cell Motil. Cytoskeleton 17:87-94.

Jung, M. K., Wilder, I. B., and Oakley, B. R. 1992. Amino acid alterations in the benA ( $\beta$-tubulin) gene of Aspergillus nidulans that confer benomyl resistance. Cell Motil. Cytoskeleton 22:170-174.

Koenraadt, H., Somerville, S. C., and Jones, A. L. 1992. Characterization of mutations in the beta-tubulin gene of benomyl-resistant field strains of Venturia inaequalis and other plant pathogenic fungi. Phytopathology 82:1348-1354.

Krasovec, M., Sanchez-Brosseau, S., and Piganeau, G. 2019. First estimation of the spontaneous mutation rate in diatoms. Genome Biol. Evol. 11:1829-1837.

Lee, M. H., Pan, S. M., Ng, T. W., Chen, P. S., Wang, L. Y., and Chung, K. R. 2011. Mutations of $\beta$-tubulin codon 198 or 200 indicate thiabendazole resistance among isolates of Penicillium digitatum collected from citrus in Taiwan. Int. J. Food Microbiol. 150:157-163.

Lee, Y. H. 2015. Meta-analysis of genetic association studies. Ann. Lab. Med. 35:283-287.

Luck, J. E., and Gillings, M. R. 1995. Rapid identification of benomyl resistant strains of Botrytis cinerea using the polymerase chain reaction. Mycol. Res. 99:1483-1488

Luo, Q. Q., Xu, J. Q., Hou, Y. P., Chen, C. J., Wang, J. X., and Zhou, M. G. 2009. PIRA-PCR for detection of Fusarium graminearum genotypes with moderate resistance to carbendazim. Plant Pathol. 58:882-887.

Ma, Z., Yoshimura, M. A., and Michailides, T. J. 2003. Identification and characterization of benzimidazole resistance in Monilinia fructicola from stone fruit orchards in California. Appl. Environ. Microbiol. 69:7145-7152.

Martin, P. L., Krawczyk, T. K., Khodadadi, F., Aćimović, S. G., and Peter, K. A. 2021. Bitter rot of apple in the Mid-Atlantic United States: Causal species and evaluation of the impacts of regional weather patterns and cultivar susceptibility. Phytopathology 111:966-981.

Martini, C., Guidarelli, M., Di Francesco, A., Ceredi, G., and Mari, M. 2016. Characterization of thiophanate methyl resistance in Italian Monilinia fructicola isolates. J. Plant Pathol. 98:453-462.

Maymon, M., Zveibil, A., Pivonia, S., Minz, D., and Freeman, S. 2006. Identification and characterization of benomyl-resistant and-sensitive populations of Colletotrichum gloeosporioides from statice (Limonium spp.). Phytopathology 96:542-548.

Moparthi, S., and Bradshaw, M. 2020. Fungicide efficacy trials for the control of powdery mildew (Podosphaera cerasi) on sweet cherry trees (Prunus avium). Biocontrol Sci. Technol. 30:659-670.
Munafò, M. R., and Flint, J. 2004. Meta-analysis of genetic association studies. Trends Genet. 20:439-444.

Nakaune, R., and Nakano, M. 2007. Benomyl resistance of Colletotrichum acutatum is caused by enhanced expression of $\beta$-tubulin 1 gene regulated by putative leucine zipper protein CaBEN1. Fungal Genet. Biol. 44:13241335.

Oliveira, M., Saraiva, D. P., Cavadas, B., Fernandes, V., Pedro, N., Casademont, I., Koeth, F., Alshamali, F., Harich, N., Cherni, L., Sierra, B., Guzman, M. G., Sakuntabhai, A., and Pereira, L. 2018. Population genetics-informed metaanalysis in seven genes associated with risk to dengue fever disease. Infect. Genet. Evol. 62:60-72.

Panagiotou, O. A., Willer, C. J., Hirschhorn, J. N., and Ioannidis, J. P. A. 2013. The power of meta-analysis in genome-wide association studies. Annu. Rev. Genomics Hum. Genet. 14:441-465.

R Core Team. 2017. R: A Language and Environment for Statistical Computing. R Foundation for Statistical Computing, Vienna, Austria. http://www. R-project.org/

Ramdial, H., Hosein, F. N., and Rampersad, S. N. 2016. Detection and molecular characterization of benzimidazole resistance among Colletotrichum truncatum isolates infecting bell pepper in Trinidad. Plant Dis. 100: 1146-1152.

Schnathorst, W. C. 1959. Spread and life cycle of the lettuce powdery mildew fungus. Phytopathology 49:464-468.

Schroeder, W. T., and Provvidenti, R. 1969. Resistance to benomyl in powdery mildew of cucurbits. Plant Dis. Rep. 53:271-275.

Schumann, G. 1991. Plant Diseases: Their Biology and Social Impact. American Phytopathological Society, St. Paul, MN.

Sholberg, P. L., and Haag, P. D. 1996. Incidence of postharvest pathogens of stored apples in British Columbia. Can. J. Plant Pathol. 18:81-85.

Sholberg, P. L., Harlton, C., Haag, P., Lévesque, C. A., O’Gorman, D., and Seifert, K. 2005. Benzimidazole and diphenylamine sensitivity and identity of Penicillium spp. that cause postharvest blue mold of apples using $\beta$-tubulin gene sequences. Postharvest Biol. Technol. 36:41-49.

Smith, C. M. 1988. History of benzimidazole use and resistance. Pages 23-24 in: Fungicide Resistance in North America. C. J. Delp, ed. American Phytopathological Society, St. Paul, MN.

USDA. 2021. Annual Cash Receipts by Commodity. Economic Research Service, U.S. Department of Agriculture, Washington, DC. https://data.ers. usda.gov/reports.aspx?ID=17832

Wang, Y., Hou, Y. P., Chen, C. J., and Zhou, M. G. 2014. Detection of resistance in Sclerotinia sclerotiorum to carbendazim and dimethachlon in Jiangsu Province of China. Australas. Plant Pathol. 43:307-312.

Yarden, O., and Katan, T. 1993. Mutations leading to substitutions at amino acids 198 and 200 of beta-tubulin that correlate with benomyl-resistance phenotypes of field strains of Botrytis cinerea. Phytopathology 83:14781483.

Young, J. R., Tomaso-Peterson, M., De la Cerda, K., and Wong, F. P. 2010. Two mutations in $\beta$-tubulin 2 gene associated with thiophanate-methyl resistance in Colletotrichum cereale isolates from creeping bentgrass in Mississippi and Alabama. Plant Dis. 94:207-212.

Ziogas, B. N., Nikou, D., Markoglou, A. N., Malandrakis, A. A., and Vontas, J. 2009. Identification of a novel point mutation in the $\beta$-tubulin gene of Botrytis cinerea and detection of benzimidazole resistance by a diagnostic PCRRFLP assay. Eur. J. Plant Pathol. 125:97-107. 